А. Б. Гынинова, Н. Б. Бадмаев. Микроморфологическая диагностика почвообразовательных процессов в почвах Еравнинской котловины Забайкалья

Научная статья

УДК 631.48

DOI 10.18101/2587-7143-2021-2-15-30

\title{
МИКРОМОРФОЛОГИЧЕСКАЯ ДИАГНОСТИКА ПОЧВООБРАЗОВАТЕЛЬНЫХ ПРОЦЕССОВ В ПОЧВАХ ЕРАВНИНСКОЙ КОТЛОВИНЫ ЗАБАЙКАЛЬЯ
}

\section{(C) Гынинова Аюр Базаровна}

доктор биологических наук, ведущий научный сотрудник, Институт общей и экспериментальной биологии СО РАН Россия, 670047, г. Улан-Удэ, ул. Сахьяновой, 6 ayur.gyninova@mail.ru

\section{(c) Бадмаев Нимажап Баяржапович}

доктор биологических наук, профессор ${ }^{1}$, заместитель директора по научной работе, заведующий лабораторией географии и экологии почв ${ }^{2}$,

${ }^{1}$ Бурятский государственный университет имени Доржи Банзарова,

${ }^{2}$ Институт общей и экспериментальной биологии СО РАН

Россия, 670000, г. Улан-Удэ, ул. Смолина 24a nima_b@mail.ru

Аннотация. Исследованы физико-химические свойства и микроморфологическое строение почв Еравнинской котловины Забайкалья. На древнеозерных равнинах под остепненными лугами формируются иллювиально-глинистые мерзлотные черноземы. Эти почвы характеризуются перераспределением тонкодисперсных фракций по профилю, значительным накоплением гумуса и высокой степенью агрегированности. В средней части профиля образуются криогенные агрегаты-ооиды, железистые нодули и карбонатные новообразования, что обусловлено увеличением концентрации раствора при промерзании или над мерзлотой. Под лиственничной тайгой на водораздельных позициях формируются криометаморфические почвы. В поверхностных горизонтах наблюдаются активная гумификация и измельчение тканей растений с образованием сложных агрегатов. Агрегаты угловатые и имеют криогенное происхождение. Агрегаты в осветленном горизонте часто упакованы в микрослои, где отмечаются признаки сепарации скелета и плазмы. В почве под березовым лесом на склоне северной экспозиции гумификация растительных остатков происходит с образованием темноцветного гумуса. В горизонтах средней части профиля агрегаты склеены железистоглинистой или глинисто-карбонатной плазмой. Согласно полученным данным, в почвах привершинной части доминируют признаки и свойства криометаморфической грубогумусовой оподзоленной почвы, в нижней части склона северной экспозиции признаки палевой темногумусной почвы.

Ключевые слова: агрегаты, глинистое вещество, железистые стяжения, кутана, карбонаты, мерзлота, микроморфология, микростроение, почвы, пылеватая фракция, структура

\section{Благодарности}

Работа выполнена при финансовой поддержке гранта РФФИ № 19-29-05250 мк и проекта НИР № 121030100228-4. 


\section{Для цитирования}

Гынинова А. Б., Бадмаев Н. Б. Микроморфологическая диагностика почвообразовательных процессов в почвах Еравнинской котловины Забайкалья // Вестник Бурятского государственного университета. Биология, география. 2021. № 2. С. 15-30.

\section{Введение}

Разнообразие почв тяжелого гранулометрического состава, формирующихся в зоне распространения многолетнемерзлых пород (ММП), представлено в Полевом определителе почв ${ }^{1} 14$ типами почв: всеми типами отделов Криометаморфические, Палево-метаморфические, Криогенные (Криоземы) и некоторыми подтипами в отделе Аккумулятивно-гумусовые. Однако существуют почвы, формирующиеся на ММП, классификационное положение которых еще не ясно. В Забайкалье к ним относятся лугово-лесные мерзлотные, мерзлотно-таежные, дерновоподзолистые мерзлотные и равнинные лугово-черноземные мерзлотные почвы $[1 ; 3 ; 7 ; 11]$. В описанных Н. А. Ногиной лугово-лесных мерзлотных почвах срединный горизонт имеет грязно-бурую окраску и нечетко выраженную комковато-творожистую структуру, т. е. признаки горизонта BPL или CRM, и может принадлежать отделу крио- или палево-метаморфических. Горные мерзлотнотаежные почвы имеют щебнистый горизонт В с заполнителем сероватокоричневого и бурого цвета. Автор объединяет в указанном типе щебнистые почвы с суглинистым и песчаным (супесчаным) заполнителем бурого цвета в срединном горизонте. Почвы с песчаным заполнителем, скорее, относятся к подбурам. Вопрос о классификационной принадлежности мерзлотно-таежных почв с суглинистыми срединными горизонтами остается открытым [5]. Дерновоподзолистые мерзлотные почвы описаны под лиственничной тайгой и имеют отчетливые признаки развития оподзоливания. Лугово-черноземные мерзлотные почвы Забайкалья характеризуются пульсирующим температурным режимом, зависящим как от скорости проникновения тепла или холода из атмосферы в толщу почвы, так и от проникновения холода из глубинных горизонтов в верхние слои [2; 7]. Согласно Н. А. Ногиной признаки поверхностной луговатости черноземов Забайкалья обусловлены биоклиматическими условиями и встречаются во всех подтипах.

В последние годы в связи с проведением V Международной конференции по криопедологии ${ }^{2}$ и всероссийской научной конференции по исследованию генезиса, географии и экологии почв холодных областей ${ }^{3}$ исследование мерзлотных почв активизировалось. В пределах Еравнинской котловины (ЕК) описаны буроземы, черноземы и вертисоли [16].

\footnotetext{
${ }^{1}$ Полевой определитель почв России. Москва: Почвенный институт им. В. В. Докучаева. 2008. $182 \mathrm{c}$.

2 Путеводитель научных экскурсий $\mathrm{V}$ Международной конференции по криопедологии / под редакцией С. В. Горячкина, Д. Е. Конюшкова, Н. С. Мергелова. Москва: ИГ РАН, 2009. $55 \mathrm{c}$.

3 Почвы холодных областей; генезис, география, экология (к столетию профессора О. В. Макеева): путеводитель научных экскурсий всероссийской научной конференции с международным участием. Улан-Удэ: Изд-во БНЦ СО РАН. 2015. 176 с.
} 
А. Б. Гынинова, Н. Б. Бадмаев. Микроморфологическая диагностика почвообразовательных процессов в почвах Еравнинской котловины Забайкалья

Целью настоящей работы является установление особенностей микроморфологического строения почв склонов теневых экспозиций возвышенностей Еравнинской котловины Забайкалья.

Объектами исследования послужили почвы катены, охватывающей вершину, северный склон и предгорную равнину горы Дархитуй (1017 м). Разрезы заложены в привершинной части, транзитной позиции на склоне и на предгорной равнине. Выбранные участки характеризуют территории с однородными крутизной и экспозицией почвообразующими породами и растительным покровом и представляют собой экологические ниши, границы которых можно обозначить по всем параметрам (табл. 1).

В Еравнинской котловине, как и в других котловинах забайкальского типа, увалы и сопки обычно изолированы друг от друга и «погружены» в осадки озерно-аллювиального и эолового генезиса. Гора Дархитуй представляет собой отдельное возвышение с чехлом рыхлых отложений, представленных продуктами выветривания гнейсов, гранитов, известняков, кристаллических сланцев, базальтов и палеобазальтов [3]. Приозерная равнина сложена аллювиально-озерными отложениями.

Таблица 1

Характеристика экологических ниш катены «Дархитуй»

\begin{tabular}{|c|c|c|c|}
\hline Фактор & \multicolumn{3}{|c|}{ Параметры экологической ниши } \\
\hline Элементы рельефа & $\begin{array}{l}\text { Привершинная } \\
\text { часть }\end{array}$ & $\begin{array}{c}\text { Средняя часть } \\
\text { склона }\end{array}$ & $\begin{array}{c}\text { Приозерная рав- } \\
\text { нина }\end{array}$ \\
\hline Высота, м & 991-1017 & 991-971 & $971-948$ \\
\hline Экспозиция & $C, C-B, C-3$ & C, $C-3, C-B$ & $p$ \\
\hline Крутизна, ${ }^{\circ}$ & $1-3$ & $2-3,3-5$ & $1-2$ \\
\hline $\begin{array}{l}\text { Положение в ландшаф- } \\
\text { те (фация) }\end{array}$ & $\ni$, ТЭ & тэ, та, а & та, a \\
\hline Рыхлая порода & Э, ЭД & Д, Дса & Д, Дса, О \\
\hline $\begin{array}{l}\text { Гранулометрический } \\
\text { состав }\end{array}$ & $\mathrm{TC}, \mathrm{C}$ & ТС, гл & с, тС, лс, сп \\
\hline Растительность & $\begin{array}{c}\text { Лиственничный лес } \\
\text { с березой }\end{array}$ & $\begin{array}{l}\text { Разнотравный } \\
\text { березовый лес }\end{array}$ & Остепненный луг \\
\hline $\begin{array}{l}\text { Глубина протаивания, } \\
\text { см }\end{array}$ & $270-300$ & $230-250$ & $275-290$ \\
\hline Испаряемость, мм & $471-522$ & $445-470$ & $471-496$ \\
\hline \multicolumn{4}{|c|}{$\begin{array}{l}\text { Условные обозначения: } \\
\text { Материнская порода (по генезису): э - элювий; ЭД - элюво-делювий; Д - делювий; } \\
\text { Дса - делювий карбонатный; О - озерные отложения. Гранулометрический состав: п - } \\
\text { песок; сп - супесь; лс - легкий суглинок; с - средний суглинок, тс - тяжелый суглинок; } \\
\text { глина. } \\
\text { Экспозиция: с - северная; с-в - северо-восточная; с-з - северо-западная; р - равнин- } \\
\text { ная. } \\
\text { Положение в ландшафте (фация): э - элювиальная, тэ - трансэлювиальная; та - тран- } \\
\text { саккумулятивная; а - аккумулятивная }\end{array}$} \\
\hline
\end{tabular}


Климат котловины характеризуется длительной холодной зимой (среднегодовая температура воздуха минус $3,0-4.1^{\circ} \mathrm{C}$ ) и коротким жарким засушливым летом. Среднегодовое количество осадков составляет 330-410 мм, почвы формируются на многолетнемерзлых породах (ММП). По данным Н. Л. Мельничук [10], мощность криолитозоны на ЮВП может доходить в среднем до 80-85 м. Условия формирования почв близки условиям, в которых формируются горные мерзлотно-таежные, лесо-луговые мерзлотные почвы и черноземы Забайкалья, описанные Н. А. Ногиной [11].

В работе использовались методы исследования морфологического строения [13]; методы исследования физико-химических свойств ${ }^{1,2}$, микроморфологические методы исследования почв ${ }^{3}[4 ; 12]$.

\section{Материалы и обсуждения}

Разрез 3E заложен в привершинной части горы Дархитуй с уклоном $\sim 1-2^{\circ}$ на запад. Местоположение: от с. Сосново-Озерское на запад 10 км. Координаты: h - 1017 м, N - 52 $31^{\circ} 04,7^{\prime \prime} ; \mathrm{E}-111^{\circ} 26^{\prime} 02,3^{\prime \prime}$.

Микрорельеф: приствольные повышения и западинки.

Растительность: лиственничный лес с березой (рис. 1б). Заросли кустарника: рододендрон даурский, спирея иволистная. В подлеске встречаются много подроста лиственницы, в напочвенном покрове - брусника, боровая матка, чина, вейник. Проективное покрытие составляет 5-10\%. Высота древостоя доходит до 30 м, сомкнутость крон составляет 0,5. Нижняя часть стволов обгорела - признаки низового пожара. Лес имеет признаки угнетенности в виде большого количества сухостоя подроста лиственницы.

Морфологическое строение профиля представлено следующими горизонтами (рис. 1a).
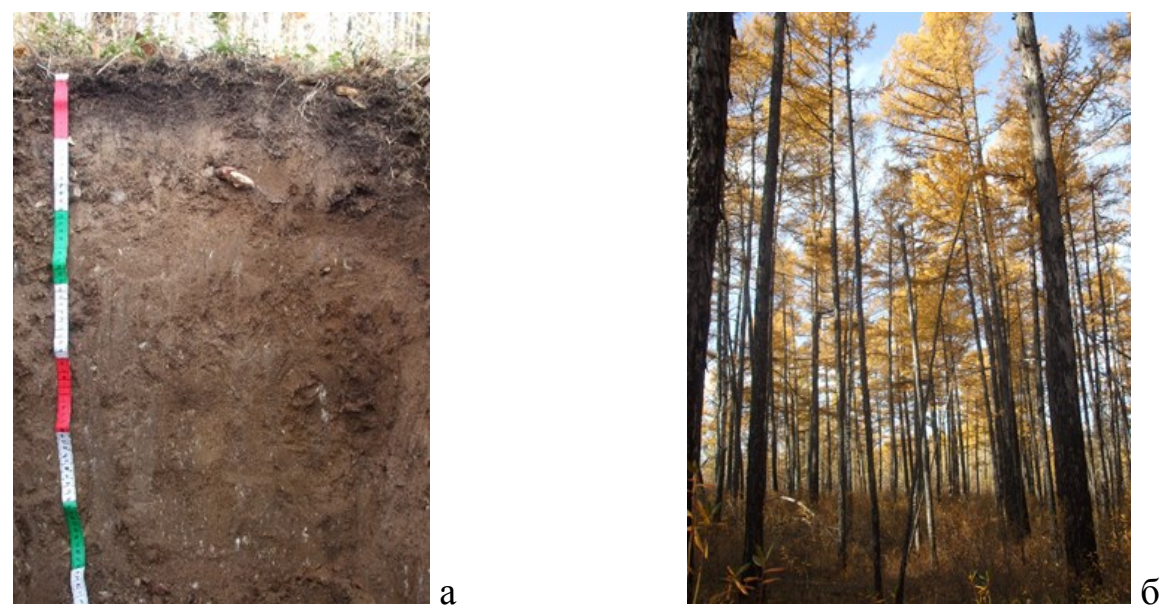

Рис. 1. Разрез ЗЕ. а - почвенный профиль; б - растительный покров

\footnotetext{
${ }^{1}$ Теории и методы физики почв. Москва: Гриф и К, 2007. 616 с.

${ }^{2}$ Теория и практика химического анализа почв. Москва: ГЕОС, 2006. 400 c.

${ }^{3}$ Interpretation of micromorphological features of soils and regoliths / eds. G. Stoops, V. Marcelino, F. Mees. Elsevier, 2010. Ch. 11, 17. P. 227-259, 375-404.
} 
А. Б. Гынинова, Н. Б. Бадмаев. Микроморфологическая диагностика почвообразовательных процессов в почвах Еравнинской котловины Забайкалья

$\mathrm{AO}(0-5 / 6$ см). Сухой опад хвои лиственницы, верхняя часть неразложившаяся, средняя часть - среднеразложившаяся, буровато-темно-серая. В нижней части выделяется подгоризонт А ферментативный органический (70-80\% органики) (4-6 см). Подгоризонт отличается темно-серой до черного окраской, обилием грибных гифов и корней. Граница слабоволнистая.

AY(5-9 см). Свежий, на буровато-сером фоне (7.5 YR 4/1) имеются буроватотемно-серые участки разлагающегося OB (7.5 YR 3/2). Рыхлый, слегка уплотнен корнями, по гранулометрическому составу - опесчаненная хрящеватая супесь, структура порошисто-комковатая, скреплена корнями. Включения большого количества корней. Граница слабоволнистая.

AYe (9-14 см). Свежий, серовато-светло-бурый (7.5 YR 5/3), плотноватый, по гранулометрическому составу - хрящеватая щебнистая опесчаненная супесь, структура творожистая рассыпчатая (d агрегатов $~ 1-3$ мм), частично скреплена корнями. Включения корней древесных растений, мелкозема значительно больше, чем в A1. Граница ровная.

CRMi (14-32 cм). Влажноватый, бурый (7.5 YR 4/4), по гранулометрическому составу - тяжелый суглинок хрящеватый с включением щебня (оглинен). Структура комковато-творожистая, сложная, мелкие агрегаты d 2-5 мм, крупные комки d 1-3 см. Плотность неравномерная, зависит от количества корней, включения щебня и древесных корней мочковатого типа, скрепляющих почву. Преобладание мелкозема, примерно 90\%. Переход постепенный, граница ровная.

CRM2 (32-53 см). Влажноватый, желтовато-бурый (7.5 YR 5/4), тяжелосуглинистый. Структура мелкотворожистая, рассыпчатая, скреплена корнями. Включения дресвы, щебня (4-10 см). Щебень разрушается руками (сапролит) и при зачистке лопатой создает белые пятна. Есть белый налет, возможно аморфный кремнезем. Очень тонкая глинистая кутана по граням агрегатов. Переход заметен по цвету. Граница ровная.

BCcrm (53-108 см). Влажноватый, буровато-желтый (10 YR 6/4), хрящеватый тяжелый суглинок, плотность неравномерная, количество камней уменьшилось, структура угловато-мелкокомковатая рассыпчатая. Включения корней редкие.

Описание морфологического строения и определение физико-химических свойств позволяют выполнить первый этап диагностики процессов, формирующих профиль. В морфологическом строении почвы разреза $3 \mathrm{E}$ выделяются горизонты: $\mathrm{AO}(0-5 / 6)-\mathrm{AY}(5 / 6-9)-\mathrm{AYE}(9-14)-\mathrm{CRMi}(14-32)-\mathrm{CRM}(32-53)-\mathrm{BC}$ crm (53-108).

Грубогумусовый горизонт АО формируется в результате разложения органического вещества (OB) с участием грибов; высокое содержание гумуса и порошисто-комковатая структура в горизонте AY свидетельствуют об активной гумификации и агрегировании; осветление горизонта АYе при очевидном влиянии грибной микрофлоры позволяет говорить о развитии процесса оподзоливания.

Процессы, формирующие горизонты CRMi, CRM и BCcrm, диагностируются по цвету и гранулометрическому составу. Содержание илистой фракции имеет максимальное значение в горизонте CRMi. Учитывая, что в оподзоленном горизонте этот показатель имеет минимальное значение, очевидно, можно говорить об элювиально-иллювиальном перераспределении, связанном с оподзоливанием и миграцией тонкодисперсных фракций до глубины 32 см. Процесс метаморфизма диагностируется по содержанию илистой фракции и начинается с глубины 14 см. При этом цвет метаморфических горизонтов меняется с глубиной. 
ВЕСТНИК БУРЯТСКОГО ГОСУДАРСТВЕННОГО УНИВЕРСИТЕТА. БИОЛОГИЯ, ГЕОГРАФИЯ

Бурый цвет горизонта CRMi, постепенно переходящий в желтовато-бурый в горизонте CRM и в желтый цвет в горизонте BCcrm, свидетельствует о том, что с глубиной изменения минералогического состава все больше включают образование лимонита, а ближе к поверхности доминируют гетит и гидрогетит.

Почвы криометаморфического отдела характеризуются присутствием в профиле горизонта CRM. Главным отличием горизонта является специфическая рассыпчатая структура: угловатая, рассыпчатая. Во влажном состоянии структура творожистая, с хорошо оформленными округлыми отдельностями размером до 5 мм.

На исследованной территории условия для формирования криометаморфических почв заключаются в следующем. Во-первых, это почвообразующая порода, представленная продуктами выветривания гнейсов, гранитов, известняков, кристаллических сланцев, базальтов и палеобазальтов [3]. Во-вторых, влиянием каменисто-валунной ММП, поддерживающей влажный режим почв благодаря конденсации атмосферной влаги и движению влаги к фронту промерзания (восходящее в зимний период и нисходящее - в летний) [14]. Зимняя аккумуляция влаги в подгумусовом горизонте, образование ледяных шлиров, их таяние и отток с влагой растворимых форм гумуса и тонкодисперсного материала, очевидно, вызывают некоторое осветление подгумусового горизонта $[6 ; 8 ; 9]$. В то же время наличие грубогумусового горизонта $\mathrm{AO}$ и кислая реакция среды с показателем $\mathrm{pH}=4,65$, несомненно, вызывают развитие процесса оподзоливания, что объясняет снижение содержания илистой фракции, гумуса, ЕКО и СНО (табл. 2). О некотором проявлении процесса текстурной дифференциации свидетельствует увеличение содержания тонкодисперсных фракции в горизонте CRMi.

Микроморфологические исследования наряду с морфологическим строением профиля обнаруживают особенности и демонстрируют характер протекания процессов. В горизонтах $\mathrm{AO}$ и $\mathrm{AY}$ потемневшие ткани растений измельчаются до размеров 10-50 мкм. Образуются органо-минеральные агрегаты сложного строения. Основу их составляют сгустки (10-50 мкм) черного ОВ. Отсутствуют признаки сепарации веществ на плазму и скелет.

Таблица 2

Физико-химические свойства почв

\begin{tabular}{|c|c|c|c|c|c|c|c|c|c|c|}
\hline \multirow[t]{2}{*}{$\begin{array}{l}\text { Горизонт, } \\
\text { глубина, см }\end{array}$} & \multicolumn{2}{|c|}{$\mathrm{pH}$} & \multicolumn{2}{|c|}{$\begin{array}{c}\text { Обменные kt, } \\
\text { г`экв/100 г }\end{array}$} & \multirow{2}{*}{\begin{tabular}{|c|}
$\begin{array}{c}\mathrm{H}^{+} \\
\text {гидр }\end{array}$ \\
мг'экв \\
\end{tabular}} & \multirow[t]{2}{*}{ EKO } & \multirow[t]{2}{*}{$\begin{array}{c}\mathrm{CHO}, \\
\%\end{array}$} & \multirow{2}{*}{$\begin{array}{c}\text { Гумус } \\
\text { общ., \% } \\
\text { (ппп) }\end{array}$} & \multicolumn{2}{|c|}{ Фракции } \\
\hline & $\mathrm{H}_{2} \mathrm{O}$ & $\mathrm{KCl}$ & $\mathrm{Ca}^{2+}$ & $\mathrm{Mg}^{2+}$ & & & & & $<0.01$ & $<0.001$ \\
\hline \multicolumn{11}{|c|}{ Разрез 3Е-2019 Дархитуй, привершинная часть } \\
\hline $\mathrm{AO}(0-5 / 6)$ & 6,53 & 6,49 & 30,00 & 1,25 & 35,9 & 67,15 & 46,54 & $(23,85)$ & & \\
\hline AY (5-9) & 6,00 & 5,34 & 19,0 & 7,0 & 3,82 & 29,82 & 87,19 & 6,33 & 28,26 & 18,63 \\
\hline AYe (9-14) & 5,97 & 4,65 & 10,2 & 4,41 & 2,62 & 17,23 & 84,79 & 1,59 & 35,00 & 13,68 \\
\hline $\begin{array}{l}\text { CRMi (14- } \\
32 \text { ) }\end{array}$ & 6,10 & 4,52 & 11,25 & 8,75 & 2,11 & 22,11 & 90,46 & 0,81 & 39,10 & 28,32 \\
\hline $\begin{array}{l}\text { CRM (32- } \\
53)\end{array}$ & 6,17 & 4,51 & 13,1 & 8,75 & 2,16 & 24,01 & 91,00 & 0,83 & 29,16 & 20,23 \\
\hline $\begin{array}{l}\text { BCcrm (53- } \\
108)\end{array}$ & 6,16 & 4,52 & 12,1 & 8,53 & 2,16 & 22,79 & 90,52 & 0,84 & 43,67 & 20,93 \\
\hline
\end{tabular}


А. Б. Гынинова, Н. Б. Бадмаев. Микроморфологическая диагностика почвообразовательных процессов в почвах Еравнинской котловины Забайкалья

\begin{tabular}{|c|c|c|c|c|c|c|c|c|c|c|}
\hline \multicolumn{11}{|c|}{ Разрез 2Е-2019, северный склон Дархитуя } \\
\hline AO 0-6 & 6,58 & 5,77 & 70,0 & 26,6 & 43,9 & 140,5 & 68,75 & $(54,12)$ & 35,1 & 20,6 \\
\hline AUyu 6-20 & 6,16 & 5,20 & 31,25 & 18,75 & 3,48 & 53,48 & 93,49 & 7,38 & 38,4 & 18,1 \\
\hline BPL 20-60 & 7,16 & 5,75 & 23,41 & 12,5 & 0,70 & 36,61 & 98,09 & 0,66 & 40,0 & 23,1 \\
\hline BCA 60-84 & 8,09 & - & - & - & - & 48,48 & 100,00 & 0,52 & 39,9 & 26,2 \\
\hline $\mathrm{BCq} 84-110$ & 8,18 & - & - & - & - & 36,0 & 100 & 0,22 & 39,4 & 24,6 \\
\hline \multicolumn{11}{|c|}{ Разрез 1E-2019 приозерная равнина (стационар «Еравна») } \\
\hline $\begin{array}{l}\text { AU дерн 0- } \\
9\end{array}$ & 6,88 & 6,66 & 31,4 & 16,6 & 5,25 & 53,25 & 90,14 & 11,36 & 25,20 & 7,56 \\
\hline$A \cup 9-24 / 25$ & 7,05 & 6,58 & 29,0 & 14,5 & 5,68 & 49,18 & 88,45 & 8,58 & 31,20 & 10,40 \\
\hline $\begin{array}{l}\text { AUBI } 24- \\
38 / 45\end{array}$ & 7,2 & 6,5 & 21,8 & 18,7 & 4,37 & 44,87 & 90,26 & 4,9 & 43,27 & 15,66 \\
\hline $\begin{array}{l}\mathrm{Bi} 38 / 45- \\
65 / 75\end{array}$ & 7,63 & - & 19,5 & 13,4 & 0,7 & 33,6 & - & 1,29 & 51,91 & 24,72 \\
\hline $\begin{array}{l}\text { BCA } 65 / 75- \\
89 / 96\end{array}$ & 8,18 & - & - & - & - & 28,52 & - & 0,84 & 54,38 & 21,01 \\
\hline $\begin{array}{l}\text { Линза } \\
\text { 89/96-110 }\end{array}$ & 8,29 & - & - & - & - & 12,35 & - & 0,67 & 51,82 & 19,58 \\
\hline $\begin{array}{l}\text { Cq89/96- } \\
180 \\
\end{array}$ & 7,85 & - & - & - & - & 36,6 & - & 0,38 & 31,01 & 8,98 \\
\hline
\end{tabular}

Признаки метаморфизма первичных минералов обнаруживаются по окрашенных в охристо-бурый цвет зонам трансформации, появлением глинистых чешуек в зонах активного выветривания, формированием автохтонной кутаны на поверхности. Указанные признаки глинистого (железисто-глинистого) метаморфизма первичных минералов обнаруживаются во всех горизонтах профиля почвы.

Микроморфологическое строение горизонта АYе имеет признаки глинистого метаморфизма первичных минералов, элювиально-глеевого процесса и криоэлювогенеза. К ним относятся признаки сепарации скелета и плазмы, на поверхности минералов прерывистые пленки толщиной 2-20 мкм представлены не только прилипшими фрагментами почвенной массы и автохтонными кутанами, но и аллохтонными. Плазма включает не только гумус и глину, но и аморфное железо, иногда образующее сгустки и нодули. Почвенная масса агрегирована, агрегаты часто упакованы в микрослои.

Признаки глинистого метаморфизма первичных минералов в горизонтах CRMi и CRM выражены ярко. Значительная часть минералов, сохраняя внешнюю форму, внутри полностью преобразована в глинистое вещество или пропитана гидрооксидами железа. Песчаные зерна покрыты сплошной плотной глинистой кутаной. Плазма глинистая, спутанно-волокнистого строения и железистоглинистая сFе-стяжениями размером $\sim 150$-мкм. Активность глинистого метаморфизма связана с податливостью к оглиниванию основных пород ${ }^{1}$. Агрегаты угловатые (образуются при криогенном растрескивании, усадочном сжатии) включают сильно выветрелые минералы размером до 50 мкм. Овальные агрегаты-ооиды диаметром> 150 мкм имеют криогенное происхождение.

\footnotetext{
${ }^{1}$ Атлас Забайкалья. Москва; Иркутск, 1967. 176 с.
} 
В горизонте BCcrm при выветривании первичных минералов появляются серые участки, вдоль трещин цвет тоже серый или буровато-серый. На поверхности минералов автохтонная кутана толщиной 10-100 мкм, прерывистая. Зерна минералов при выветривании приобретают бурый или серый цвет, а по трещинам охристо-бурый. Плазма тонкопылевато-глинистая и глинистая, железистая желтовато-коричневая. Диагностируется сепарация (обособление) глинистой плазмы оттонкопылеватых частиц. В этом случае глинистая плазма приобретает потечные формы. Отличительной чертой морфологического строения является мелкокомковатая структура. Микроморфологическое исследование обнаруживает угловатую форму микроагрегатов размером 100-1000 мкм, упакованных компактно. Яркое проявление агрегирования в горизонте ВCcrm свидетельствует о том, что этот процесс не является чисто почвенным, а, скорее, связан с промерзанием, протаиванием и миграцией влаги под влиянием температурного градиента.

Степень выветривания по сравнению с горизонтами CRMi и CRM небольшая, т. е. глинистый метаморфизм наиболее активен в почвенных горизонтах. Но в горизонте BCcrm метаморфизм также получает развитие, а агрегирование не менее активно, чем в почвенных горизонтах, т. е. сама почвообразующая порода метаморфизована и агрегирована и формирование этих признаков не обязательно связано с почвенными процессами. Почвообразование происходит на щебнистосуглинистом субстрате, испытывающем глинистый метаморфизм и агрегирование. Почвообразование усиливает развитие этих процессов.

Почва может относиться к типу криометаморфическая грубогумусовая (при наличии горизонта АO) или дерновая (при наличии горизонта AY). Учитывая, что грубогумусовый горизонт имеет значительную мощность и хорошо развит, а гумусовый горизонт имеет небольшую мощность, очевидно, почву следует отнести к грубогумусовой. В соответствии с формулой профиля, физикохимическими свойствами и микроморфологическим строением предлагается название почвы - криометаморфическая темногумусовая. Название предварительное и требует аналитического подтверждения поведения форм соединений железа и состава гумуса.

Разрез 2E заложен в транзитной части склона северной экспозиции горы Дархитуй (9 км на восток от с. Сосново-Озерск) крутизной 2-3 с отметкой 971 м. Координаты: $\mathrm{N}-52^{0} 52^{\prime} 507^{\prime \prime}, \mathrm{E}-111^{0} 47^{\prime} 038^{\prime \prime}$.

Растительность: разнотравный березовый лес (рис. 2б) с единичным подростом лиственницы (9Б $+1 Л)$. Сомкнутость крон 70\%, высота древостоя - 20-25 м. В кустарниковом ярусе встречается ерник. Напочвенный покров представлен разнотравьем (осока стоповидная, кровохлебка лекарственная, вейник sp, тысячелистник, осока sp.) и зеленым мхом, перекрытыми свежим опадом березы. В микрорельефе приствольные повышения, западины.

Профиль почвы состоит из горизонтов АO (0-6 см) - AUуu (6-20 см) CRMf (20-60 см) - CRMca (60-84 см) - BCq (84-110 см) и пересекается крупными магистральными трещинами, заполненными темно-серой до черного почвенной массой (рис. 2a).

АО 0-6 см. Под свежим опадом березовых листьев бурая слаборазложившаяся лесная подстилка, ниже - среднеразложившаяся темно-бурая (7.5YR 2.5/2). Граница слабоволнистая. 
А. Б. Гынинова, Н. Б. Бадмаев. Микроморфологическая диагностика почвообразовательных процессов в почвах Еравнинской котловины Забайкалья

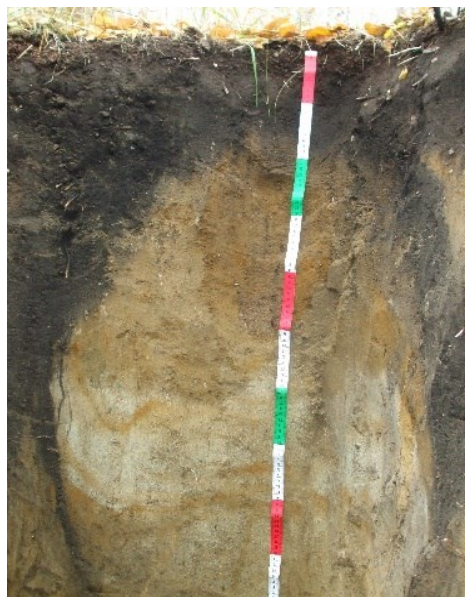

a

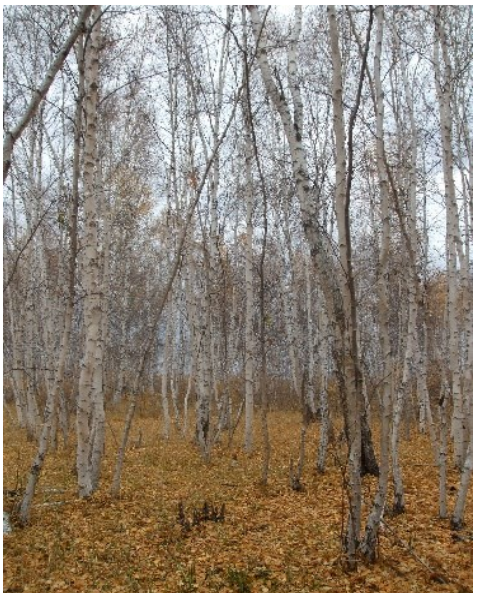

6

Рис. 3 Разрез 2Е. а - профиль почвы, б - растительный покров

AUуu 6-20 см. Влажноватый, буровато-темно-серый до черного (7.5YR 2.5/1). Плотный, суглинистый, структура порошисто-комковатая. Включения дресвы размером 1,5-2,0 см, много корней. Переход заметен по цвету. Граница волнистая. Очень крупные клиновидные затеки до глубины 100 см.

Клиновидный затек 20-100 см. Влажноватый, черного цвета (10YR 2/1), плотный, среднесуглинистый, структура творожисто-комковатая. Включения древесных корней. Не вскипает под воздействием $10 \% \mathrm{HCl}$.

BPL 20-60 см. Свежий, желтовато-светло-бурый с охристыми пятнами (10YR 5/4), плотный, прерывистый, влажный, среднесуглинистый. Структура творожисто-глыбистая. Немногочисленные включения древесных корней. Охристые пятна размером $\sim 5$ см. Под воздействием $10 \% \mathrm{HCl}$ вскипает слабо. Переход заметен по цвету. Граница волнистая.

BCA 60-84 см. Свежий, желтовато-белесый (10YR 5/4) со светло-охристыми горизонтально ориентированными, иногда криогенно деформированными полосами, средне- или тяжелосуглинистый, очень плотный, структура творожистокомковатая с горизонтальной делимостью. Включения камней редкие. Новообразования: охристые и бурые пятна. Под воздействием $10 \% \mathrm{HCl}$ вскипает бурно. Переход заметен по цвету. По нижней границе проходит охристая полоса. Граница волнистая.

ВСq 84-110 см. Свежий, неоднородно окрашен: белесовато-желтоватый и белесовато-серый с оливковым оттенком (2.5Y 6/3), весьма плотный, среднесуглинистый. Структура творожисто-глыбистая. Включения мертвых древесных корней единичные, охристые пятна. Под воздействием $10 \% \mathrm{HCl}$ вскипает бурно.

Аккумулятивный горизонт буровато-темно-серый до черного, легкосуглинистый, порошисто-комковатый с мощными клиновидными затеками. Содержание гумуса в аккумулятивном горизонте более $6 \%$, реакция слабокислая близкая к нейтральной, ниже - слабощелочная и щелочная (табл. 2).

Желтовато-светло-бурые тона окраски, творожистость структуры горизонтов BPLи BCA требуют дополнительных объяснений процессов их образующих. 
Скорее это криогенное агрегирование и железистый метаморфизм с образованием гидрооксидов железа и минералов бурого и желтого цветов, а также аккумуляция карбонатов. Для почвы характерна высокая ЕКО и насыщенность основаниями во всех горизонтах, кроме АО. Гранулометрический состав на границе среднего и тяжелого суглинка, резких изменений состава по горизонтам профиля не обнаруживается. Биогенное накопление обменных оснований на фоне лесного почвообразования, образование клиновидных затеков, повышение содержания илистой фракции в горизонтах BPL и ВCA свидетельствуют о том, что они соответствуют типу «лугово-лесные», по Н. А. Ногиной и типу «дерновые серые лесные» - по Ц. Х. Цыбжитову [15]. По Классификации почв России ${ }^{1}$ почва более близка к типу «палевая темно-гумусовая».

Микроморфологическое строение почвы разреза 2Е обнаруживает аналогичную направленность процесса гумификации в горизонте АО с почвой привершиной части. В нижней части лесной подстилки почерневшее и побуревшее органическое вещество разрушается до частиц размером 20-30 мкм. Гумусовый горизонт AUyu агрегирован. Агрегаты сложные. Первичные агрегаты органические, черные, имеют размер 20-100 мкм. Вторичные агрегаты имеют размеры 0,5-2 мм и включают первичные агрегаты, зерна песка, пыли. Зерна первичных минералов «облеплены» общей массой и в том числе первичными агрегатами. Наблюдается активная метаморфизация первичных минералов: побурение, оглинивание, образование на поверхности минералов автохтонной кутаны толщиной 3-5 мкм. Плазма органо-Fе-глинистая, бурая. Отмечается слабая криогенная сепарация [9] на тонкую пыль и глину.

Микростроение горизонта BPL плазменно-песчаное. Плазма черно-бурая, заполняет поры. Обилие рудных сильно выветрелых минералов, оглинивающихся или приобретающих аморфную форму. Много биотита побуревшего и оглиненного. Встречаются зерна кальцита. Кутана автохтонная со слабыми признаками подвижности.

Микростроение горизонта ВСА песчано-пылевато-плазменное. Много сильно выветрелых пластинок биотита и полевого шпата с трещинами, прокрашенными гидрооксидами железа и глинистыми образованиями внутри. Обилие дисперсных криптозернистых (размером 2-3 мкм) кристаллов карбонатов, заполняющих поры и покрывающих минералы.

Микростроение горизонта ВСq включает плазму, пыль и песчаные зерна; соотношение фракций примерно равное. Плазма представлена аморфными черными и бурыми сгустками размером 10-20 мкм. Среди зерен минералов обилие биотита, черных, желтых и зеленых минералов, продуктов гидрометаморфизма. Зерна минералов покрыты кутаной толщиной 10 мкм.

Анализ полученных данных свидетельствует о том, что особенности строения почвы заключаются в образовании гумусной плазмы черного цвета, образующей частицы размером 10-50 мкм, активном оглинивании минералов, высвобождении железа из кристаллической решетки минералов и образовании аморфных гидрооксидов, выпадении из растворов криптозернистых форм карбонатов и агрегировании. Почвообразующая порода испытывает также активный метамор-

${ }^{1}$ Полевой определитель почв России. Москва: Почвенный институт им. В. В. Докучаева, 2008. 182 c. 
А. Б. Гынинова, Н. Б. Бадмаев. Микроморфологическая диагностика почвообразовательных процессов в почвах Еравнинской котловины Забайкалья

физм. Микроморфологическое строение подтверждает развитие процессов: активная гумификация и агрегирование в гумусовых горизонтах и активное оглинивание, ожелезнение, агрегирование, карбонатизация - в минеральных горизонтах.

Таким образом, профиль почвы формируется под влиянием следующих процессов в горизонтах: AO - активная гумификация; AUуu - активная гумификация и агрегирование; BPL — активное оглинивание, ожелезнение и агрегирование, слабая карбонатизация; ВСА - активное оглинивание, карбонатизация, агрегирование; $\mathrm{BCq}$ - агрегирование, слабый гидрометаморфизм; гумусовый затек (20-100 см): метаморфизм, агрегирование. Образование гумусового затека скорее приурочено к плейстоценовому времени, так как он по цвету и структуре очень сильно отличается от современного гумусового горизонта.

Название почвы - палевая темногумусовая - предварительное и требует аналитического подтверждения поведения форм соединений железа и состава гумуса.

Разрез 1E заложен на приозерной равнине, юго-восточной окраине с. Сосно-

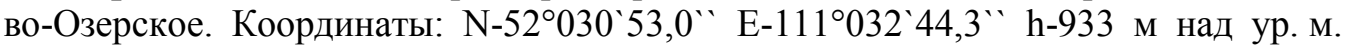
Рельеф равнинный, слабоволнистый с уклоном $0,5^{\circ}$ в сторону озера Большое Еравнинское. Бугры пучения (d 3-5 м, h 30-40 см).

Растительность луговая, представлена злаково-пырейно-разнотравным сообществом (рис. 3б), включающим виды: осока твердоватая, кровохлебка лекарственная, полынь (монгольская). Высота травостоя 20 см. (Злаки $60 \mathrm{~cm}$, осока твердоватая 4 см). Проективное покрытие 70-80\%.

Почвенный профиль состоит из горизонтов АUдерн (0-9 см) - AU (924/25см) - AUBI (24/25-38/45 см) - Bi (38/45-65/75 см) - BCA (65/75-89/96 см) - BCса (89/96-150 см) - Сq (150-180 см) (рис. 3a).
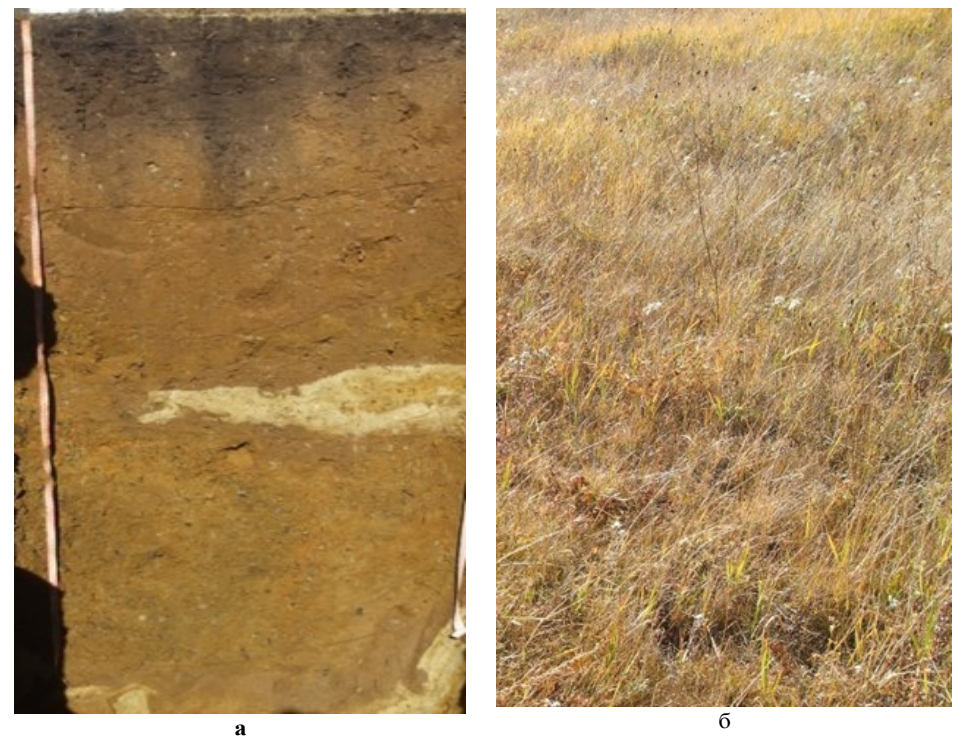

Рис. За. Разрез 1Е. а - профиль почвы, б - растительный покров 
ВЕСТНИК БУРЯТСКОГО ГОСУДАРСТВЕННОГО УНИВЕРСИТЕТА.

AUдерн. (0-4/9) см. Свежий, буровато-темно-серый (10YR 3/1), структура порошисто-комковатая, скреплен и уплотнен корнями. Гранулометрический состав: дресвянистый средний суглинок с включением щебня. Обилие мелких корешков ( $10 \%$ от ОМ). Переход заметен по содержанию корней. Граница неровная, волнистая (4-9 см).

$\mathrm{AU}(9-24 / 25)$ см. Свежий, темно-серый до черного (10YR 2/1), прерывистый, местами выклинивается. Очень плотный, среднесуглинистый, структура мелкокомковатая с элементами ореховатости и пластинчатости. Включения щебня и дресвы, щебнистая часть полуокатанная. Количество корней среднее. Переход постепенный. Нижняя граница с клиновидными затеками. Гумусовый горизонт проникает в виде клиньев в области трещин до 43-45 см, при глубоких трещинах до глубины 80-90 см.

AUB (24/25-38/45) см. Влажноватый, неоднородно окрашен, желтоватосветло-бурый (10YR 5/4) с темно-серыми гумусовыми клиновидными затеками горизонт. Тяжелосуглинистый, дресвянистый, крупные отдельности дресвы полуокатаны. Включения щебня полуокатанного. Структура комковатая. Небольшое включение корней. Гумусовые затеки из $\mathrm{AU}$ (до 90 см) влажноватые, по центру темно-серые, по краям серые, плотные, среднесуглинистые, структура порошисто-комковатая, хорошо выражена. Включения дресвы небольшого количества корней. Переход по включению (отсутствию) гумусовых затеков. Граница неровная.

Bi (38/45-65/75) см. Влажный, желтовато-светло-бурый (10YR 5/6), плотный, структура комковатая с элементами ореховатости, по граням структурных отдельностей тонкая кутана, среднесуглинистый, дресвянистый, крупные фракции дресвы полуокатаны. Небольшое количество включений корней. Граница волнистая, переход заметен по цвету.

ВСса (65/75-89/96) см. Влажный, желтовато-бурый с сероватым или оливковым оттенком (10YR 5/3), структура глыбисто-творожисто-комковатая, тяжелосуглинистый. Включения дресвы, щебня. В нижней части новообразованная карбонатная линза длиной $\sim 50$ см, высотой 20 см. Цвет белесый с желтоватостью (2.5Y 8/2 paleyellow), с бледно-охристыми и темно-охристыми примазками, пятнами. Вскипает при воздействии $\mathrm{HCl}$. Переход заметный по цвету и структуре. Белесые новообразования вскипают бурно.

Сса (89/96-150) см. Влажный, желтовато-коричневый с оливковым оттенком (10YR 7/4), плотный, структура глыбисто-комковатая с элементами ореховатости, глинистый, на гранях структурных отдельностей кутана. Белесые (2.5Y 8/2), карбонатные новообразования, четко отграниченные от ОМ. Много включений крупного хряща, мелкого щебня, корней нет. Граница неровная, переход заметен по цвету и гранулометрическому составу. Вскипает при воздействии $\mathrm{HCl}$.

D (150-180) см. Влажный, неоднородно окрашен, основной фон бурый с оливковым оттенком (2.5Y 8/2), структура глыбисто-комковатая с ореховатостью, плотный, глинистый. Включений дресвы и щебня нет. Не вскипает при воздействии $\mathrm{HCl}$.

Формула профиля соответствует типу «чернозем глинисто-иллювиальный». В горизонтах BCA, BCca, Cq белесые, карбонатные, четко отграниченные от ОМ новообразования белесого с желтоватостью цвета, с бледно-охристыми и темно- 
А. Б. Гынинова, Н. Б. Бадмаев. Микроморфологическая диагностика почвообразовательных процессов в почвах Еравнинской котловины Забайкалья

охристыми примазками и пятнами являются свидетельством гидрометаморфизма, связанного с влиянием мерзлоты.

Специфика строения профиля заключается в том, что почва дресвянистая, а подстилающая порода не содержит грубого материала. Очевидно, это обусловлено влиянием ММП, увлажняющей почву и тем самым активизирующей глинистый метаморфизм в нижней части профиля больше, чем в вышележащих горизонтах. Еще одной причиной может быть выдавливание каменистых фракций к поверхности из мерзлого слоя. Не исключена и исходная двучленность, когда озерная фация перекрывается делювием. Высокое содержание гумуса, постепенное его уменьшение с глубиной, суглинистый состав, нейтральная реакция в верхней части, щелочная среда и карбонатность - в нижней части профиля, высокая ЕКО и насыщенность основаниями (табл. 2) - характерные черты черноземов.

Микроморфологическое строение почвы обнаруживает активную гумификацию остатков растений с образованием гумуса mull в горизонтах AUдерн. Плазма органическая, микроагрегирована, упаковка рыхлая. Микростроение горизонта AU песчано-пылевато-плазменное с гумусно-глинистой плазмой и высокой степенью агрегированности. Агрегаты сложные, состоят из глинисто-гумусных, размером 10-30 мкм (микроагрегатов), объединяющихся в более крупные структурные отдельности округлой или неправильной формы, размером 100-400 мкм и до 2-3 мм.

В горизонте Вi поверхности зерен крупных фракций покрыты глинистой плазмой. Глинистая плазма имеет сплошное волокнистое строение, с образованием агрегатов-ооидов, отмечается сепарация на пылеватую и плазменную составляющие - признаки криогенеза. Формирование нодулей также может быть обусловлено увеличением концентрации раствора при промерзании.

Нижерасположенный горизонт ВСА отличается слабовыраженным агрегированием, более компактным сложением. Центрами ожелезнения служат сильновыветрелые Fe-содержащие минералы.

Почвообразующая порода Сq отличается карбонатностью и отсутствием грубодисперсных фракций. Первичные минералы представлены небольшим количеством тонкой пыли. Плазма глинистая и карбонатно-глинистая. Глинистая плазма имеет сплошное волокнистое и крапчатое микростроение с небольшим включением тонкой пыли. Карбонатно-глинистая плазма обособлена и образует округлые размером 10-20 мкм и более крупные (до 100 мкм) неправильной формы микроновообразования. Отмечаются признаки дифференциации на плазму и скелет. Агрегаты с тонкопылевато-железистой ВПМ, размером 0,5-2 мкм (1), стонкопылевато-карбонатно-глинистой внутрипедной массой (ВПМ), размером 0,5-2 мм (2) и с карбонатно-глинистой волокнистой ВПМ, размером 100 мкм (3). Это или агрегаты-блоки иногда соединившиеся или агрегаты неправильной формы.

Агрегаты (1) и (2) покрыты карбонатно-глинистой волокнистой плазмой и нередко представляют собой оглиненные метаморфизованные первичные минералы с большим количеством тонкодисперсных первичных минералов и сгустков глинистой плазмы. Иногда встречаются нодули размером 100-1000 мкм. Центрами ожелезнения служат сильновыветрелые Fe-содержащие минералы. 
Исследование микроморфологического строения обнаруживает значительную роль криогенного фактора в агрегировании почвенной массы, а также в развитии гидрометаморфизма и формировании карбонатных новообразований. Возможно, исследованные почвы следует отнести к черноземам иллювиально-глинистым, мерзлотным.

Влияние многолетней мерзлоты оказывает большое влияние на все почвообразовательные процессы всех исследованных типов почв. К ним относятся очень активный глинистый метаморфизм и гумификация в условиях повышенной влажности, создаваемой ММП. Повсеместное активное образование темноцветных форм гумуса в виде сгустков размером 10-50 мкм (микроагрегированность гумуса). Динамика температур и влажности в сезонноталом слое обусловливает морозное агрегирование с формированием слоистой текстуры в осветленном горизонте горно-таежной почвы, криогенных агрегатов-ооидов, аллохтонных кутан в подгумусовом горизонте, микроновообразований карбонатов в нижней части профиля равнинной почвы, дисперсность карбонатов в почвах нижней части склона.

Таким образом, профиль сформировался под влиянием следующих процессов: активная гумификация с образованием гумуса mull, агрегирование в горизонтах $\mathrm{AUдерн.,} \mathrm{AU,} \mathrm{AUB;} \mathrm{криогенное} \mathrm{агрегирование,} \mathrm{слабая} \mathrm{иллимеризация} \mathrm{в} \mathrm{горизон-}$ те Вi; слабое агрегирование, формирование карбонатных линз в горизонте ВСА; слабое агрегирование, формирование карбонатных стяжений, гидрометаморфизм в ВСса; в горизонте $\mathrm{Cq}$ - слабое агрегирование формирование карбонатных стяжений, гидрометаморфизм. Почва относится к типу «чернозем иллювиальноглинистый мерзлотный».

\section{Заключение}

Активная гумификация и значительное содержание глинистого компонента, обусловленное податливостью к метаморфизму вулканических пород, являются диагностическими признаками криометаморфических почв на юге Витимского плоскогорья. Таежный тип гумификации опада обусловливает некоторое развитие оподзоливания, что позволяет отнести криометаморфические почвы к грубогумусовым оподзоленным.

В транзитной части склона северной экспозиции на почвообразующей породе, представленной карбонатными продуктами выветривания палеоген-неогеновых вулканических пород темного цвета, формируются почвы, соответствующие по микроморфологическим признакам (высокая степень оструктуренности, железистые и железисто-глинистые пленки, прокрашивающие горизонт BPL в желтобурый цвет, карбонатная пропитка горизонта BCA, придающая белесый цвет, активная гумификация с образованием гумуса mull) палевых темногумусовых почв.

Чернозем глинисто-иллювиальный мерзлотный имеет все признаки указанного подтипа: гумификация с образованием гумуса mull, криогенная оструктуренность, карбонатность.

Выполненные исследования свидетельствуют о том, что почвы исследованной катены образуют ряд, включающий предположительно криометаморфическую грубогумусовую оподзоленную почву, палевую темногумусовую почву и чернозем глинисто-иллювиальный мерзлотный. 
А. Б. Гынинова, Н. Б. Бадмаев. Микроморфологическая диагностика почвообразовательных процессов в почвах Еравнинской котловины Забайкалья

\section{Литература}

1. Бадмаев Н. Б. Мерзлотный режим катен Еравнинской котловины Байкальского региона // География и природные ресурсы. 1997. № 2. С. 179-183. Текст: непосредственный.

2. Информационно-картометрическая оценка связей в системе «почва - среда» / Н. Б. Бадмаев, В. М. Корсунов, А. И. Куликов, Н. К. Бадмаева // География и природные ресурсы. 2000. № 2. С. 142-148. Текст: непосредственный.

3. Базаров Д.-Д. Б. Кайнозой Прибайкалья и Западного Забайкалья. Новосибирск: Наука, 1986. 172 с. Текст: непосредственный.

4. Герасимова М. И., Губин С. В., Шоба С. А. Микроморфология почв природных зон СССР. Пущино, 1992. 215 с. Текст: непосредственный.

5. Герасимова М. И. Классификация почв России: путь к следующей версии // Почвоведение. 2019. № 1. С. 32-42. Текст: непосредственный.

6. Гынинова А. Б. Влияние криогенных факторов на морфогенез луговых подбелов Приамурья // Вестник МГУ. 2008. № 3. С. 10-14. Текст: непосредственный.

7. Дугаров В. И., Куликов А. И. Агрофизические свойства мерзлотных почв, Новосибирск: Наука, 1990. 255 с. Текст: непосредственный.

8. Ершов Э. Д. Влагоперенос и криогенные текстуры в дисперсных породах. Москва: Изд-во Моск. ун-та, 1979. 214 с. Текст: непосредственный.

9. Ершов Э. Д. Физико-химия и механика мерзлых пород. Москва: Изд-во Моск. ун-та, 1986. 214 с. Текст: непосредственный.

10. Мельничук Н. Л. Подземные воды Еравнинского и Верхне-Удинского артезианского бассейнов // Методика гидрогеологического исследования и ресурсы подземных вод Сибири и Дальнего Востока. Москва: Наука, 1966. С. 217-227. Текст: непосредственный.

11. Ногина Н. А. Почвы Забайкалья. Москва: Наука, 1964. 314 с. Текст: непосредственный.

12. Парфенова Е. И., Ярилова Е. А. Руководство к микроморфологическим исследованиям в почвоведении. Москва: Наука, 1977. 198 с. Текст: непосредственный.

13. Розанов Б. Г. Морфология почв. Москва: Академический проект, 2004. 431 с. Текст: непосредственный.

14. Тютюнов И. А. Процессы изменения и преобразования почв и горных пород при отрицательной температуре. Москва: Изд-во АН СССР, 1960. 144 с. Текст: непосредственный.

15. Цыбжитов Ц. Х., Цыбжитов А. Ц. Почвы бассейна оз. Байкал. Генезис и географияи классификация степных и лесостепных почв. Улан-Удэ: Изд-во БНЦ СО РАН, 2000. 165 с. Текст: непосредственный.

16. Vertic soils and Vertisols in cryogenic environments of southern Siberia, Russia / I. V. Kovda, S. V. Goryachkin, M. P. Lebedeva [at al.] // Geoderma Volum 288, 15 February 2017, Pages 184-195. Текст: непосредственный.

Статья поступила в редакцию 17.03.2021; одобрена после рецензирования 08.04.2021; принята к публикаичи 26.04.2021. 


\section{MICROMORPHOLOGICAL DIAGNOSTICS OF THE PEDOGENIC PROCESSES IN SOILS OF ERAVNINSKAYA DEPRESSION IN TRANSBAIKALIA}

Ayur B. Gyninova

Dr. Sci. (Biol.), Chief Researcher,

Institute of General and Experimental Biology SB RAS

6 Sakhyanovoy St., Ulan-Ude 670047, Russia

ayur.gyninova@mail.ru

Nimazhap B. Badmaev

Dr. Sci. (Biol.), Prof. ${ }^{1}$,

Deputy Director for Research, Head of Geography and Soil Ecology Laboratory ${ }^{2}$

${ }^{1}$ Dorzhi Banzarov Buryat State University

${ }^{2}$ Institute of General and Experimental Biology SB RAS

24a Smolina St., Ulan-Ude 670000, Russia

nima_b@mail.ru

Abstract. We have investigated the physico-chemical properties and micromorphological structure of the soils of Eravninskaya Depression in Transbaikalia. The Luvic Chernozem (Tonguic) is formed on the ancient lake plains under the steppe meadows. These soils are characterized by redistribution of finely dispersed fractions along the profile, significant accumulation of humus, and a high degree of aggregation. In the middle part of the profile cryogenic ooid aggregates, ferruginous nodules and carbonate neoformations are formed due to an increase in the concentration of the solution above permafrost or during freezing. Cryometamorphic soils are developed under the larch taiga at watersheds. In the surface horizons it is observed active humification and reduction of plant tissues with the formation of complex aggregates. The aggregates are angulate and have cryogenic origin. The aggregates in the whitened horizon are often packed in microlayers with signs of skeleton and plasma separation. In the soil under a birch forest, on the slope of the northern exposure, plant residues are humified with the formation of dark-colored humus. In horizons of the middle part of the profile, the aggregates are glued together by ferruginous-argillaceous or argillaceous-carbonate plasma. According to the data obtained, the features and properties of Skeletic Folic Cryosol (Nechic) soil dominate in the soils of the upper part, and the features of Folic Phaeozem (Colluvic, Tonguic) - in the lower part of the northern exposure slope.

Keywords: aggregates, argillaceous matter, ferruginous concretions, cutan, carbonates, permafrost, micromorphology, microstructure, soils, silt fraction, structure

\section{Acknowledgments}

The work was carried out with the financial support of the RFBR grant No. 19-29-05250 mk and the research project No. 121030100228-4.

\section{For citation}

Gyninova A. B., Badmaev N. B. Micromorphological Diagnostics of the Pedogenic Processes in Soils of Eravninskaya Depression in Transbaikalia. Bulletin of Buryat State University. Biology. Geography. 2021; 2: 15-30 (In Russ.).

The article was submitted 17.03.2021; approved after reviewing 08.04.21; accepted for publication 26.04.2021. 